\title{
Cultivation of oyster mushrooms (Pleurotus species) to improve the in vitro dry matter digestibility of wheat straw for feeding to ruminants
}

H Omed, A Avagyan, M Hale, J Gibbons

Bangor University, Bangor, Gwynedd, Wales, United Kingdom

Email:h.omed@bangor.ac.uk

Introduction Wheat straw is an underutilized energy resource for animals: it is indigestible and has a low protein content. Most methods for improving the digestibility are not cost effective or have potential health and environmental hazards. This paper focuses on using a biological pre-treatment with Pleurotus spp, lignin degrading white-rot fungi, to improve wheat straw from low to high available energy feed. Pleurotus spp. are able to degrade the lignin in a selective way (Kerem \& Hadar, 1993) thus making cellulose available for ruminants. Pleurotus spp. are widely cultivated worldwide to produce oyster mushrooms and have a high protein content, are free from cholesterol and are rich in carbohydrates, fibre, vitamins and minerals (Kues \& Liu, 2000). Pleurotus spp. also have a medicinal potential. The aims of this study were to investigate the ability of different Pleurotus spp. to increase the protein content, degrade lignin and improve digestibility of the wheat straw. Production of edible mushrooms was also considered.

Material and methods Five Pleurotus spp. were screened for their ability to increase the protein content, degrade lignin and improve digestibility of wheat straw. Four of the Pleurotus strains used came from local resources (P. ostreatus: P. ost x TW, P. ost x TG, Po x K; P. florida) and 1 commercial strain of $P$. pulmonarius was purchased (Mycelia, Ghent, Belgium). Wheat grain was infected to inoculate straw. Straw was chopped into lengths of 3-5 cm and soaked in water for 20 mins and left to drain. Culture bags were each filled with $1 \mathrm{~kg}$ of soaked straw and a microelement solution was added (Per bag: $\mathrm{ZnSO}_{4} .7 \mathrm{H}_{2} \mathrm{O}: 0.017 \mathrm{mg}, \mathrm{MgSO}_{4} .7 \mathrm{H}_{2} \mathrm{O}: 0.32 \mathrm{mg}$ and $\mathrm{CuSO}_{4}: 0.025 \mathrm{mg}$ ). Bags were autoclaved sterilised and inoculated by adding $60 \mathrm{~g}$ of colonised grain. Bags were sealed and incubated for 19 or 42 days in total, in duplicate. Those which were incubated for 42 days in total were incubated for 19 days for colonisation at $22{ }^{\circ} \mathrm{C}, 65 \%$ relative humidity, 1 day cold shock at $10{ }^{\circ} \mathrm{C}$ and 22 days fruiting at $24{ }^{\circ} \mathrm{C}, 75 \%$ relative humidity with a 10 hours per day light cycle (470-700 $\mathrm{nm})$. In the final stage pinholes were made in bags to support air exchange and this allowed emergence and proper development of fruit bodies. The other set of bags were incubated for 19 days as above. For each treatment, 2 bags without fungal inoculation were used as controls. Crude protein, and lignin content were determined (Halliday 1985), while the Modified Faeces Liquor technique (Omed et al. 1989) was used for digestibility estimation. The statistical analysis was performed using SPSS 14.2.

Results During the experiment all strains produced fruit bodies, but not all fruiting bodies reached the point of harvest at the experiment end. Increases in digestibility and crude protein were highly significant $(\mathrm{p}=0.000)$, especially after 42 days incubation but lignin decreases were not $(\mathrm{p}=0.386)$ (Tables 1-3).

Table 1 Relative increase compared to control, *statistically different from the control $(\mathrm{p}<0.01))$

\begin{tabular}{|c|c|c|c|c|c|c|}
\hline \multirow[t]{2}{*}{ Strain } & \multicolumn{2}{|c|}{ Digestibility (\%) } & \multicolumn{2}{|c|}{ Crude protein $(\%)$} & \multicolumn{2}{|c|}{ Lignin (\%) } \\
\hline & 19 days & 42 days & 19 days & 42 days & 19 days & 42 days \\
\hline P. ostreatus x TG & 23.92 & $103.77 *$ & $54.94 *$ & $141.55^{*}$ & 7.61 & 20.93 \\
\hline P. ostreatus $\mathrm{x}$ TW & 9.57 & $91.19 *$ & $55.64 *$ & $128.97 *$ & 20.41 & 6.5 \\
\hline P. ostreatus x K & $50.25 *$ & $125.78 *$ & $83.75^{*}$ & $121.38 *$ & 13.77 & 19.63 \\
\hline P. pulmonarius & $57.41 *$ & $125.78 *$ & $66.80^{*}$ & $69.22 *$ & 13.30 & 13.72 \\
\hline P. florida & 19.13 & $116.35 *$ & $71.45^{*}$ & $160.81 *$ & 9.08 & 9.95 \\
\hline \multicolumn{7}{|c|}{ Table 2 Pooled SEM } \\
\hline Treatment & \multicolumn{2}{|c|}{ Pooled SEM for IVDMD (\%) } & \multicolumn{3}{|c|}{ Pooled SEM for crude protein (\%) } & Polled SEM for Lignin ( $\%)$ \\
\hline 19 days & \multicolumn{2}{|l|}{1.0775} & \multicolumn{2}{|l|}{0.055} & \multicolumn{2}{|c|}{0.45} \\
\hline 42 days & \multicolumn{2}{|l|}{0.9601} & \multicolumn{2}{|l|}{0.064} & \multicolumn{2}{|c|}{0.78} \\
\hline
\end{tabular}

Table $3 \mathrm{P}$ value for the effect of straw source, Pleurotus species, and interaction between straw source and Pleurotus species.

\begin{tabular}{llll}
\hline \hline Analysis & Effect of straw source & Effect of Pleurotus spp. & Effect of straw source and Pleurotus spp. \\
\hline Protein & $\mathrm{p}=0.000$ & $\mathrm{p}=0.000$ & $\mathrm{p}=0.000$ \\
Lignin & $\mathrm{p}=0.03$ & $\mathrm{p}=0.94$ & $\mathrm{p}=0.356$ \\
Digestibility & $\mathrm{p}=0.000$ & $\mathrm{p}=0.000$ & $\mathrm{p}=0.000$ \\
\hline \hline
\end{tabular}

Conclusions This study showed that with fungal treatment it was possible to achieve increase in digestibility with small reductions in total lignin content $(2-5 \%$ lignin $)$. Combined with this were significant crude protein increases. These improvements increased with longer incubation periods. However the extent of the changes in digestibility, crude protein and lignin content was strain specific. The current research demonstrated that it is possible significantly increase digestibility, protein content of wheat straw and produce edible fruit bodies at the same time. It can be also assumed that feeding animals with protein enriched substrate and transformed substrate will not only constitute feed but may also be beneficial due to the immuno-stimulation properties of Pleurotus. The cultivation of Pleurotus species is also an economically sound strategy to convert agro-residues into nutritional foods and medicinal products.

References

Halliday, J.L. 1985. Studies of rumen degradation in relation to the utilisation of forage. PhD thesis. University of Wales,

Bangor.

Kerem, Z. and Hadar, Y. 1993. Applied and Environmental Microbiology 59, 4115-4120.

Kues, U. \& Liu, Y. 2000. Applied Microbial Biotechnology, 54, 141-152.

Omed, H., Axford, R.F.E., Chamberlain, A.G. and Givens, D.I. 1989. Journal of Agricultural Animal Science 126, 235-248 